groups: University of Bristol : Research Group in Neurosecretion in the Department of Pharmacology (Prof. H. Heller) for research on the ultrastructure and function of the hypothalamo-hypophysial system, and on the distribution and identification of neurosecretory products and their actions and metabolism throughout the vertebrate phylum. University of Edinburgh: Research Group on Bacterial Enzyme Variation, in the Department of Molecular Biology (Prof. M. R. Pollock), for research on the enzymatic basis of variation and adaptation in microorganisms. St. Mary's Hospital Medical School, London: Research Group on the Structure and Biological Activities of Antibodies and Protein Antigens in the Department of Immunology (Prof. R. R. Porter), for research on the structure of antibodies and the means by which their structure enables them to combine specifically with antigens.

\section{Academician Nikolai Vavilov Prize}

The Soviet Academy of Sciences has instituted an Academician Nikolai Vavilov Prize, to be awarded for outstanding achievements in genetics, selection and plant breeding every three years, on November 26-Vavilov's birthday. Academician Vavilov was responsible for many major discoveries in biology, and for laying the foundation for many new lines of research in botany, plant breeding, genetics and selection. A large plant collection of more than 300,000 varietios was amassed under his direction, representing the flora of the world; this has formed an experimental base for developing now varieties of farm crops in the U.S.S.R. and abroad. Nikolai Vavilov was the first president of the Soviet Agricultural Academy and headed the plant breeding institute. It is good to record that Vavilov has now, posthumously, been restored, by the Russians, to the honourable place which he rightfully deserves in Soviet science-a place which he has always held in the eyes of Western scientists.

\section{The University Grants Committee}

To fill vacancies on the University Grants Committee, Mr. Anthony Crosland, the Secretary of State for Education and Science, has announced four new appointments. The new members are: J. W. Atwell, managing director of G. and J. Weir, Ltd., Glasgow; Prof. C. E. H. Bawn, Grant Brunner professor of inorganic and physical chemistry, University of Liverpool; Prof. R. C. Cross, Regius professor of logic, University of Aberdeen; Prof. J. Diamond, Beyer professor of mechanical engineering, University of Manchester. Three members of the Committee, whose terms of office had expired, have been re-appointed. They are: Sir Eric Ashby, Master of Clare College, University of Cambridge; Prof. F. W. Rogers Brambell, Lloyd Roberts professor of zoology, University College of North Wales, Bangor; Prof. C. H. Philips, professor of oriental history and director of the School of Oriental and African Studies, University of London.

\section{National College of Rubber Technology}

AT a meeting held at the Department of Education and Science between representatives of the Department and the University Grants Committee, the Inner London Education Authority, Loughborough University-desig. nate, the Northern Polytechnic, the National College of Rubber Technology and the industry, it was agreed that a postgraduate centre of polymer technology, developing the work at present done at the National College of Rubber Technology, should be established in the new University at Loughborough. The University Grants Committee has invited the University-designate at Loughborough to submit detailed plans as soon as possible for the necessary buildings and equipment for 100 students in the first instance. This is on the understanding that the industry will meet the cost of residential accommodation. It is proposed that the National College shall come to an end when the new centre has been established, but the Department of Education and Science and the Inner London Education Authority will make arrangements for work, up to and including degree level, to continue and to be developed as necessary in London in order to match the needs of the industry.

\section{New Steering Committee for Hydraulics Research}

THE Minister of Technology has appointed a Steering Committee to be responsible for the general supervision of the research programme and work of the Ministry's Hydraulics Research Station at Wallingford, Berkshire. This Committee has now established three specialist committees on coastal engineering and harbours, on rivers and estuaries, and on hydraulic structures and hydroelectrics, and an Inter-Departmental Liaison Committee will be appointed to maintain and strengthen links with other Government Departments. These changes came about owing to the fact that the previous arrangements, whereby the Council for Scientific and Industrial Research was advised by the Hydraulics Research Board on the work of the Station, automatically came to an end when the Council and the Department of Scientific and Industrial Research were dissolved on March 31, 1965.

The members of the Steering Committee for Hydraulics Research are: Dr. B. K. Blount (chairman); Prof. J. Allen; Dr. E. Lee; T. A. L. Paton; R. C. H. Russell (director of hydraulics research); E. B. Wright (secretary). The Committee's terms of reference are: "To be responsible to the Minister of Technology for the general supervision of the work of the Hydraulics Research Station and for the allocation of effort thereon within the financial resources assigned to the Station and such other limits as the Minister may impose".

The three specialist committees are to advise the Steering Committee on the programme of work of the Station in the fields for which they are responsible. The chairman of each of the committees is: R. C. H. Russell (coastal engineering); Prof. J. Allen (rivers and estuaries); T. A. L. Paton (hydraulic structures and hydro-electrics). The other members of the committees have yet to be nominated.

\section{Voluntary Services Overseas}

IN a written answer in the House of Commons on July 9, Mr. A. E. Oram, the Parliamentary Secretary to the Ministry of Overseas Development, stated that the number of graduate volunteers serving overseas under the Voluntary Service Overseas Scheme had risen from 36 in $1962-63$ to 255 in $1963-64$, to 507 in $1964-65$, and was expected to reach $900-950$ in $1965-66$ and 1,300 in 1966-67. On July 13, also in a written answer, Mr. Oram stated that of 113 short-term appointments, mainly for agricultural graduates, which the Ministry of Overseas Development or the Department of Technical Co-operation had been asked to fill in Africa, during mid-1962 to mid1965,48 were to research posts and 65 to advisory or executive posts. Of these 113 officers, 36 had had formal training in tropical agricultural subjects as postgraduate students, and most of the others would have acquired specialized knowledge of tropical agriculture before selection. He estimated that the Department would probably make about 60 appointments in the next 12 months, of which about one-third would be for research.

\section{University Foundation of Brussels}

THE forty-fourth annual report of the Univorsity Foundation of Brussels covering the year ended September 30,1964 , in which grants totalling $6 \cdot 3$ million francs were made, includes a tribute to its honorary President, Baron Holvoct, on his ninetieth birthday (Pp. 190. Bruxelles: Fondation Universitaire, 1965). Study grants totalling 561,000 franes were made to 19 students at the universities of Brussels, Louvain, Liège and Ghent, and five subsi- 